\title{
Anticancer activities of tanshinone microemulsion against hepatocellular carcinoma in vitro and in vivo
}

\author{
HUI MA, QING FAN, JIA YU, JILE XIN and CE ZHANG
}

Department of Pharmacy, The Second Affiliated Hospital of Dalian Medical University, Dalian, Liaoning 116027, P.R. China

Received June 14, 2012; Accepted October 3, 2012

DOI: $10.3892 / \mathrm{mmr} .2012 .1129$

\begin{abstract}
The natural product tanshinone (Tan) induces apoptosis and differentiation in hepatocellular carcinoma (HCC) cells, but its clinical use is limited by its poor water solubility and the lack of appropriate formulations. In this study, Tan was encapsulated into a microemulsion (ME) composed of phospholipid, ethyl oleate, glycerol and Pluronic F68. The anticancer effects and mechanisms of action of Tan ME were tested using in vitro and in vivo HCC models. The mRNA and protein levels of apoptosis related molecules (Bcl-2 and Bax) were analyzed in H22 murine hepatoma cells and H22 tumor-bearing mice by flow cytometry, RT-PCR and immunofluorescence staining. Compared with empty ME and drug solution groups, the mRNA levels of Bax were upregulated and the mRNA and protein levels of $\mathrm{Bcl}-2$ were downregulated in the H22 cells treated with Tan ME in a dose-dependent manner. The mRNA and protein levels of Bax were upregulated and the Bcl-2 levels were downregulated in the H22 tumors of animals treated with Tan ME in a dose-dependent manner. Our results suggest that as a drug delivery system, the ME enhances the antitumor effect of Tan.
\end{abstract}

\section{Introduction}

Hepatocellular carcinoma (HCC) is the sixth most common tumor worldwide but, due to its poor prognosis, it ranks as the third most common cause of mortality from cancer (1). Surgical therapy, chemotherapy and radiation have been used for the treatment of HCC. However, HCC remains one of the more difficult cancers to treat. Although chemotherapy is a common therapeutic strategy following surgery, it is toxic to normal tissues and this limits its use (2). Therefore, it is important to develop safer and more effective drugs for the treatment of HCC.

Danshen has been used to treat various diseases, including heart disease, hepatitis and cancer, in China for a long time (3).

Correspondence to: Dr Qing Fan, Department of Pharmacy, The Second Affiliated Hospital of Dalian Medical University, 467 Zhongshan Road, Shahekou District, Dalian, Liaoning 116027, P.R. China

E-mail: fq731@sina.com

Key words: tanshinone microemulsion, $\mathrm{H} 22$, Bax, Bcl-2, apoptosis
Tanshinone (Tan) is the major lipid-soluble pharmacological constituent of danshen (4). The diterpenoid Tan, which includes Tan I, Tan IIA, Tan IIB, dihydrotanshinone I and cryptotanshinone, has also roused extensive attention. Tanshinones have a variety of biological activities. For example, Tan I is able to enhance learning and memory, while Tan IIA has antioxidative, anti-inflammatory, antiproliferative and antitumor properties $(5,6)$. Previous studies have shown that Tan IIA possesses cytotoxic activity against multiple human cancer cells, inducing apoptosis and differentiation in certain human cancer cells, including HeLa and colo205 cells $(7,8)$. However, the applications of Tan have been limited due to its poor solubility, instability and low bioavailability. The poor water solubility is likely to induce opsonization and cause rapid clearance from the blood circulation following intravenous injection. Therefore, there is a need for a better drug delivery system (DDS) for Tan.

Numerous methods have been used to improve the absorption and bioavailability of poorly water-soluble drugs. One of the more attractive types of system is a microemulsion (ME) which is composed of fine oil-in-water droplets in an aqueous medium (9). As a DDS approach, MEs are clear, stable, isotropic mixtures of oil, water and surfactant, frequently in combination with a cosurfactant (10). MEs offer an interesting and potentially quite powerful alternative carrier system for drug delivery due to their high solubilization capacity, transparency, thermodynamic stability, ease of preparation and high diffusion and absorption rates when compared with solvents without the surfactant system (11).

In the present study, Tan was encapsulated into an ME to provide a Tan ME formulation. The apoptosis- and differentiation-inducing effects of Tan ME were investigated in H22 cells in vitro and in vivo.

\section{Materials and methods}

Chemicals and reagents. Tan was purchased from Chiatai Qingchunbao Pharmaceutical Co., Ltd. (Hangzhou, China). 5-Fluorouracil (5-Fu) was purchased from Tianjin Jinyao Amino Acid Co., Ltd. (Tianjin, China). RPMI-1640, FBS and penicillin-streptomycin were purchased from Hyclone Corporation (Logan, UT, USA). Rabbit anti-mouse Bax polyclonal and mouse anti-human Bcl-2 monoclonal antibodies were purchased from Santa Cruz Biotechnology, Inc. (Santa Cruz, CA, USA). FITC-conjugated goat anti-mouse IgG and 
Table I. Primer sequences for PCR and amplification conditions for each target gene.

\begin{tabular}{|c|c|c|c|}
\hline Gene name & Primer sequence ( $5^{\prime}$ to $\left.3^{\prime}\right)$ & Product (base) & Amplification conditions \\
\hline Bax & $\begin{array}{l}\text { F: CGGCGAATTGGAGATGAACTG } \\
\text { R: GCAAAGTAGAAGAGGGCAACC }\end{array}$ & 161 & $\begin{array}{l}\text { Bax: Denaturation at } 94^{\circ} \mathrm{C} \text { for } 1 \text { min, annealing at } \\
60^{\circ} \mathrm{C} \text { for } 1 \text { min and synthesizing at } 72^{\circ} \mathrm{C} \text { for } 30 \mathrm{sec} \\
\text { for } 35 \text { cycles }\end{array}$ \\
\hline Bcl-2 & $\begin{array}{l}\text { F: TACCGTCGTGACTTCGCAGAG } \\
\text { R: GGCAGGCTGAGCAGGGTCTT }\end{array}$ & 350 & $\begin{array}{l}\mathrm{Bcl}-2 \text { and } \beta \text {-actin: Denaturation at } 94^{\circ} \mathrm{C} \text { for } 1 \mathrm{~min} \text {, } \\
\text { annealing at } 62^{\circ} \mathrm{C} \text { for } 1 \mathrm{~min} \text { and synthesizing at } \\
72^{\circ} \mathrm{C} \text { for } 1 \mathrm{~min} \text { for } 35 \text { cycles }\end{array}$ \\
\hline$\beta$-actin & $\begin{array}{l}\text { F: TACCACAGGCATTGTGATGG } \\
\text { R: AATAGTGATGACCTGGCCGT }\end{array}$ & 310 & \\
\hline
\end{tabular}

TRITC-conjugated goat anti-mouse IgG were purchased from KPL Inc. (Gaithersburg, MD, USA). TRIzol reagent was purchased from Invitrogen Life Technologies (Carlsbad, CA, USA). The Takara RNA PCR kit (AMV) Ver3.0 was purchased from Takara Biotechnology Co., Ltd. (Dalian, China).

Animals and cell lines. H22 murine hepatoma cells were purchased from the Department of Pathology, Dalian Medical University. Male and female Balb/c mice, weighing 20.0 $\pm 2.0 \mathrm{~g}$, were obtained from the Animal Facility of Dalian Medical University. The animals were maintained in a room with a controlled environment (12-h light/dark cycle, $24 \pm 2^{\circ} \mathrm{C}$ ). They were also given free access to standard laboratory diet and water. All experiments were approved by the Animal Research Ethics Committee of Dalian Medical University.

Preparation of Tan ME. According to our previous study (12), $160 \mathrm{mg}$ Tan was dissolved in $38 \mathrm{~g}$ ethyl oleate using ultrasound, to form the oil phase of the ME. A mixture of $5.4 \mathrm{~g}$ phospholipid, $6 \mathrm{~g}$ glycerol, $10.6 \mathrm{~g}$ pluronic $\mathrm{F} 68$ and $140 \mathrm{ml}$ sterile water formed the aqueous phase of the ME. The oil and aqueous phases were heated to $65^{\circ} \mathrm{C}$. The oil phase was added to the aqueous phase with magnetic stirring (Diamond, Jin Tian, China). The obtained emulsion was sheared using a high shearing emulsifier (FLUKO, Essen, Germany) for $5 \mathrm{~min}$; an amount of water was then added to compensate for that lost by evaporation. The ME was emulsified further using a high pressure homogenizer (Mizuho, Osaka, Japan) under $85 \mathrm{MPa}$ for $10 \mathrm{~min}$ and filtered through a $0.45-\mu \mathrm{m}$ filter membrane. The ME was transferred to a 1-ml ampoule, sealed with $\mathrm{N}_{2}$ and flow steam sterilized for $20 \mathrm{~min}$.

Cell culture and chemical treatment. $\mathrm{H} 22$ cells were routinely cultured in RPMI-1640 medium with $10 \%$ (v/v) FBS, penicillin $(100 \mathrm{U} / \mathrm{ml})$ and streptomycin $(100 \mathrm{U} / \mathrm{ml})$ at $37^{\circ} \mathrm{C}$ in a humidified $5 \% \mathrm{CO}_{2}$ incubator. Exponentially growing cells were exposed to 0.2 or $0.8 \mu \mathrm{g} / \mathrm{ml}$ concentrations of Tan ME for $48 \mathrm{~h}$. The control groups were cells grown in medium containing an equivalent amount of empty ME or Tan solution.

Measurement of Bcl-2 expression by flow cytometry (FCM). FCM was performed as reported previously (13). At least 5,000 events were collected for each sample and washed with phosphate-buffered saline (PBS). After centrifugation, the cell pellet was resuspended in the fixation/permeabilization solution at $4^{\circ} \mathrm{C}$ for $15 \mathrm{~min}$. The cells were then incubated with the mouse anti-human Bcl-2 monoclonal antibody at $4{ }^{\circ} \mathrm{C}$ for $20 \mathrm{~min}$ in the dark. After washing twice in PBS, the cells were incubated with the FITC-conjugated goat anti-mouse IgG at $4^{\circ} \mathrm{C}$ for $20 \mathrm{~min}$ in the dark. After washing twice in PBS, the cells were analyzed using a FACScan flow cytometer and Cell Quest software (BD Biosciences, San Jose, CA, USA).

$R T$-PCR assay. Total RNA was extracted from the tumor tissues or cells using TRIzol reagent. The quality and concentration of the RNA were confirmed by spectrophotometry and electrophoresis on ethidium bromide-stained agarose gels. The RT-PCR amplification was performed using the Takara RNA PCR kit (AMV) Ver 3.0. The specific primers and the amplification conditions are shown in Table I. The initial denaturation step for all genes was set at $94^{\circ} \mathrm{C}$ for $5 \mathrm{~min}$. Finally, an additional extension step at $72^{\circ} \mathrm{C}$ for 5 min was performed. The PCR products were analyzed by electrophoresis on a $3 \%$ agarose gel with EB staining using a Gel-Pro analyzer (UVP, Upland, CA, USA).

Animals and experimental protocol. The H22 cells were collected from the ascites of the mice 8 days after inoculation to prepared a cell suspension of concentration $5.0 \times 10^{6} / \mathrm{ml}$. The $\mathrm{Balb} / \mathrm{c}$ mice received a subcutaneous injection of $\mathrm{H} 22$ cells $\left(1.0 \times 10^{6}\right.$ in $\left.0.2 \mathrm{ml}\right)$ in the right axillary region (14). From the second day after inoculation, the Balb/c mice were randomly divided into 6 groups (10/group; half male and half female). There were 3 Tan ME treatment groups comprising 3 intravenous (i.v.) dose levels (2, 4 and $8 \mathrm{mg} / \mathrm{kg}$ ); a positive control group treated with $5-\mathrm{Fu}[25 \mathrm{mg} / \mathrm{kg}$, intraperitonealy (i.p.)]; a negative control group which received an i.v. injection of empty ME; and a Tan control group which received a solution of Tan at an i.v. dose of $8 \mathrm{mg} / \mathrm{kg}$. The treatments were given daily for 7 consecutive days. Prior to each treatment, the mice were weighed. At the end of the experiment, all mice were sacrificed by dislocation and the body, tumor and spleen weights were determined. The tissue samples were stored at $-80^{\circ} \mathrm{C}$ until analysis. The tumor inhibition rate and spleen index were calculated as follows: inhibition rate $(\%)=(1-$ tumor weight of test group/tumor weight of Tan solution group) x100; spleen index $=$ spleen weight $(\mathrm{mg}) /$ body weight $(\mathrm{g})$.

Immunofluorescence staining. Double immunofluorescence staining was performed as described previously $(6,15)$. Tumor 

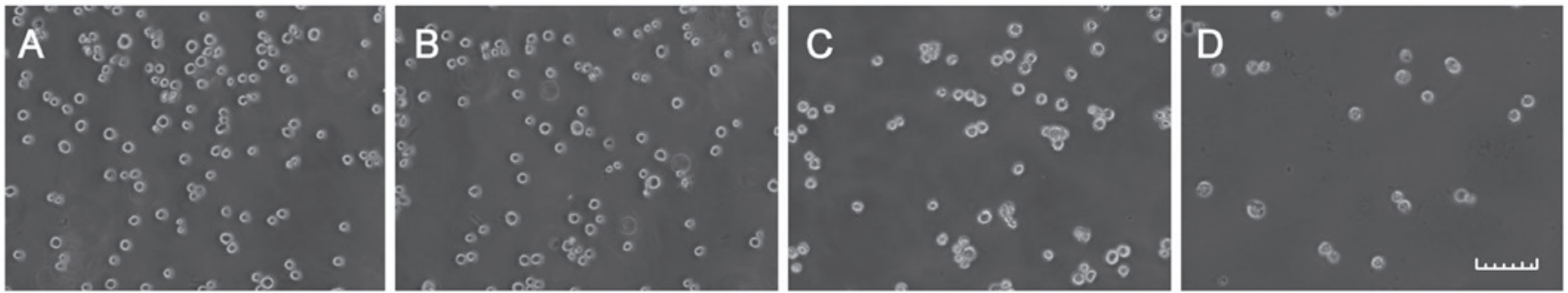

Figure 1. Tanshinone microemulsion (Tan ME) induced morphological changes in H22 cells. (A) Empty ME; (B) Tan solution (0.8 $\mu \mathrm{g} / \mathrm{ml})$; (C) Tan ME $(0.2 \mu \mathrm{g} / \mathrm{ml}) ;(D)$ Tan ME $(0.8 \mu \mathrm{g} / \mathrm{ml})$. Bar, $40 \mu \mathrm{m}$.


Figure 2. Effects of tanshinone microemulsion (Tan ME) on Bcl-2 expression in H22 cells. (a) Representative flow cytometry data. (b) Quantitative data. (A) Empty ME; (B) Tan solution $(0.8 \mu \mathrm{g} / \mathrm{ml})$; (C) Tan ME $(0.2 \mu \mathrm{g} / \mathrm{ml})$; (D) Tan ME $(0.8 \mu \mathrm{g} / \mathrm{ml})$. ${ }^{* *} \mathrm{P}<0.01$ compared with the Tan solution group.

tissues were removed immediately en bloc and post-fixed for $24 \mathrm{~h}$ in $4 \%$ paraformaldehyde in PBS at $4^{\circ} \mathrm{C}$ before cryoprotection by bathing in $30 \%$ sucrose. They were then frozen and $6-8-\mu \mathrm{m}$ sections were prepared using a cryostat (Leica CM1850; Mannheim, Germany). The sections were rinsed with PBS 3 times for 5 min each, covered with $1 \%$ SDS solution and then incubated for $5 \mathrm{~min}$ at room temperature. After rinsing with PBS 3 times for 5 min each, the sections were treated with $0.3 \%$ Triton X-100, blocked with $10 \%$ horse serum and then incubated with mouse anti-human Bcl-2 monoclonal antibody (1:75) and rabbit anti-mouse Bax polyclonal antibody (1:75) at $4^{\circ} \mathrm{C}$ overnight. After a PBS wash, the slides were incubated with the FITC-conjugated goat anti-mouse IgG (1:75) and TRITC-conjugated goat anti-mouse IgG (1:75) for $1 \mathrm{~h}$ at room temperature. The nuclei were stained with DAPI. The images of double-immunostained sections were acquired with a fluorescence microscope (Nikon, TE2000U, Tokyo, Japan).

Statistical analysis. The results are expressed as the means \pm SD. Comparisons of each group were performed by one-way analysis of variance (ANOVA) using SPSS 13.0 software. $\mathrm{P}<0.05$ was considered to indicate a statistically significant result.

\section{Results}

Tan ME induces morphological changes in H22 cells. Under an inverted light microscope, empty ME-treated and Tan solution-treated $\mathrm{H} 22$ cells grew well and the cell skeletons were clear. The majority of cells treated with 0.2 or $0.8 \mu \mathrm{g} / \mathrm{ml}$ Tan ME for $48 \mathrm{~h}$ were broken and necrosed (Fig. 1).

Tan ME downregulates Bcl-2 protein levels in vitro. The effects of the different treatments on $\mathrm{Bcl}-2$ protein levels were evaluated by FCM analysis (Fig. 2). High levels of the Bcl-2 protein were detected by FCM $48 \mathrm{~h}$ after empty ME treatment and the Tan solution-treated group had markedly decreased Bcl-2 protein levels compared with the empty ME-treated group. Tan $\mathrm{ME}$ decreased $\mathrm{Bcl}-2$ protein levels markedly compared with those of the Tan solution-treated group, in a dose-dependent manner $(\mathrm{P}<0.01)$.

Tan ME downregulates Bcl-2 mRNA levels and upregulates Bax mRNA levels in vitro. Using semi-quantitative RT-PCR, we first examined the effects of Tan ME on the mRNA levels of Bcl-2 and Bax in cultured H22 cells. As shown in Fig. 3, Bax mRNA expression levels were low in the Tan solution 
Table II. Effects of body weight, spleen index and inhibition rate for H22 hepatic carcinoma in mice treated with Tan ME.

\begin{tabular}{|c|c|c|c|c|c|c|}
\hline \multirow[b]{2}{*}{ Group } & \multirow{2}{*}{$\begin{array}{c}\text { Dose } \\
(\mathrm{mg} / \mathrm{kg})\end{array}$} & \multicolumn{2}{|c|}{ Body weight (g) } & \multirow{2}{*}{$\begin{array}{l}\text { Spleen index } \\
(\mathrm{mg} / \mathrm{g})\end{array}$} & \multirow{2}{*}{$\begin{array}{l}\text { Tumor weight } \\
\text { (g) }\end{array}$} & \multirow{2}{*}{$\begin{array}{c}\text { Inhibition rate } \\
(\%)\end{array}$} \\
\hline & & Pre-medication & Post-medication & & & \\
\hline Empty ME & 8 & $20.10 \pm 1.93$ & $22.75 \pm 2.05$ & $8.01 \pm 0.70$ & $1.12 \pm 0.18$ & - \\
\hline $5-\mathrm{Fu}$ & 25 & $20.48 \pm 1.56^{\mathrm{a}}$ & $17.98 \pm 1.88$ & $3.65 \pm 0.40^{b}$ & $0.37 \pm 0.07^{\mathrm{b}}$ & 65.79 \\
\hline \multirow[t]{2}{*}{ Tan solution } & 8 & $17.87 \pm 0.51$ & $21.20 \pm 2.65$ & $8.10 \pm 1.24$ & $1.08 \pm 0.30$ & - \\
\hline & 2 & $19.40 \pm 1.15$ & $22.20 \pm 4.39$ & $9.93 \pm 1.35$ & $1.09 \pm 0.17$ & -0.89 \\
\hline \multirow[t]{2}{*}{ Tan ME } & 4 & $19.93 \pm 1.79$ & $21.93 \pm 3.56$ & $8.93 \pm 0.48$ & $1.01 \pm 0.12$ & 6.33 \\
\hline & 8 & $18.45 \pm 1.08$ & $19.60 \pm 2.26$ & $9.60 \pm 1.12$ & $0.56 \pm 0.08^{a}$ & 47.66 \\
\hline
\end{tabular}

$\mathrm{n}=10$ per group; mean $\pm \mathrm{SD}$. Tan, tanshinone; $\mathrm{ME}$, microemulsion; 5 -Fu, 5 -fluorouracil. ${ }^{\mathrm{a}} \mathrm{P}<0.05,{ }^{\mathrm{b}} \mathrm{P}<0.01$ vs. the Tan solution group.
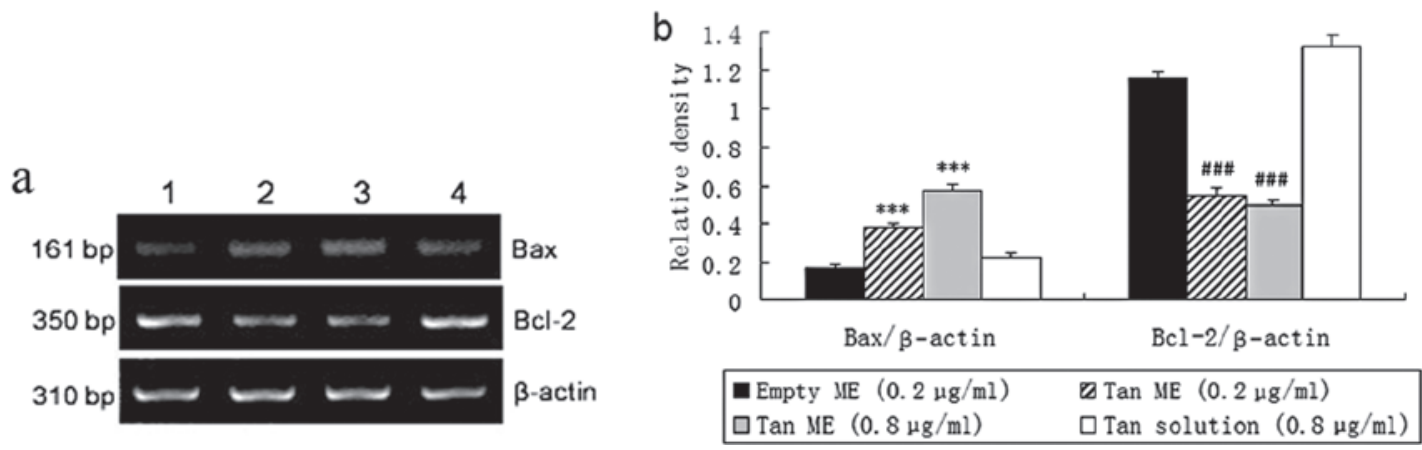

Figure 3. Effects of tanshinone microemulsion (Tan ME) on Bax and Bcl-2 mRNA levels in vitro. (a) Representative RT-PCR results. (b) Quantitative data mean+SD, ${ }^{* * *} \mathrm{P}<0.001$ compared with the level of Bax mRNA in the Tan solution group; ${ }^{\# \# *} \mathrm{P}<0.001$ compared with the level of Bcl-2 mRNA in the Tan solution group. Lane 1, empty ME; lane 2, Tan ME (0.2 $\mu \mathrm{g} / \mathrm{ml})$; lane 3, Tan ME (0.8 $\mu \mathrm{g} / \mathrm{ml})$; lane 4, Tan solution $(0.8 \mu \mathrm{g} / \mathrm{ml})$.



Empty ME



Tan

solution



Tan ME



Tan ME

$4 \mathrm{mg} / \mathrm{kg}$



Empty ME

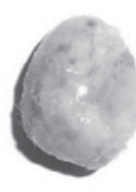

Tan



Tan ME Tan ME
$2 \mathrm{mg} / \mathrm{kg} \quad 4 \mathrm{mg} / \mathrm{kg}$



Figure 5. Images of tumors from the treated rats. Bar, $1 \mathrm{~cm}$. Tan, tanshinone; ME, microemulsion.

Figure 4. Images of spleens from the treated rats. Bar, $1 \mathrm{~cm}$. Tan, tanshinone; $\mathrm{ME}$, microemulsion.

group, but 0.2 and $0.8 \mu \mathrm{g} / \mathrm{ml}$ Tan ME increased the mRNA levels of Bax. In the Tan solution group, Bcl-2 mRNA was highly detectable and 0.2 and $0.8 \mu \mathrm{g} / \mathrm{ml}$ Tan ME markedly decreased the levels of Bcl-2 mRNA $(\mathrm{P}<0.001)$.

Tan ME inhibits tumor growth in vivo. The treatment with $8 \mathrm{mg} / \mathrm{kg}$ Tan ME demonstrated significant inhibitory effects on the growth of the inoculated $\mathrm{H} 22$ cells in the mice; the inhibition rate was $47.66 \%$. No significant differences in the tumor growth between the 2 and $4 \mathrm{mg} / \mathrm{kg}$ Tan ME-treated groups and the Tan solution-treated group were observed (Table II). As a positive control, $5-\mathrm{Fu}(25 \mathrm{mg} / \mathrm{kg})$ significantly inhibited tumor growth but it also decreased the mean body weight and spleen index of the mice (Figs. 4 and 5).

Tan ME treatment downregulates Bcl-2 and upregulates Bax $m R N A$ levels in H22 tumors in vivo. As shown in Fig. 6, Tan ME increased Bax mRNA levels in a dose-dependent manner $(\mathrm{P}<0.001)$. Compared with the Tan solution-treated group, the Bcl-2 mRNA levels were significantly decreased in the tumors from the mice treated with $2 \mathrm{mg} / \mathrm{kg}$ Tan ME $(\mathrm{P}<0.01)$ or 4 or $8 \mathrm{mg} / \mathrm{kg}$ Tan ME $(\mathrm{P}<0.001)$.

Tan ME treatment modulates the distributions of Bcl-2 and Bax in H22-transplanted tumors. We found little staining of Bax and strong staining of Bcl-2 in the Tan solution-treated 

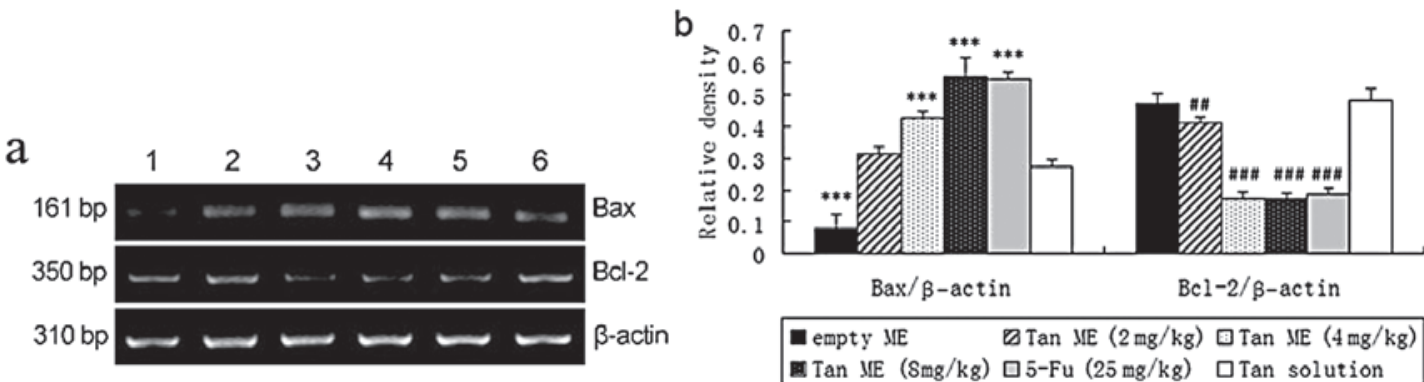

Figure 6. Effects of tanshinone microemulsion (Tan ME) on Bax and Bcl-2 mRNA levels in H22 tumors in vivo. (a) Representative RT-PCR results (b) Quantitative data mean+SD, ${ }^{* * *} \mathrm{P}<0.001,{ }^{\# \#} \mathrm{P}<0.01,{ }^{\# \# \#} \mathrm{P}<0.001$ compared with the level of Bcl-2 mRNA in the Tan solution group. Lane 1, empty ME; lane 2, Tan ME (2 mg/kg); lane 3, Tan ME (4 mg/kg); lane 4, Tan ME (8 mg/kg); lane 5: 5-fluorouracil (5-Fu; $25 \mathrm{mg} / \mathrm{kg}) ;$ lane 6, Tan solution (8 mg/kg).



Figure 7. Double immunofluorescence for Bax and Bcl-2 with DAPI counterstaining in the cytoplasms of H22-transplanted tumors. The localization of Bax and $\mathrm{Bcl}-2$ in the cytoplasms of the H22-transplanted tumors was analyzed by immunostaining with TRITC-labeled anti-rabbit IgG against rabbit anti-Bax antibody and FITC-labeled anti-mouse IgG against mouse anti-Bcl-2 antibody. Nuclei were stained with DAPI. Bax immunostaining appeared red, Bcl-2 immunostaining appeared green and DAPI staining appeared blue. Bar, $40 \mu \mathrm{m}$. Tan, tanshinone; ME, microemulsion. 
tumor tissue by immunohistochemistry. Compared with the Tan solution group, 4 and $8 \mathrm{mg} / \mathrm{kg}$ Tan ME markedly increased Bax and decreased Bcl-2 in a dose-dependent manner (Fig. 7).

\section{Discussion}

In our study, Tan was encapsulated into an ME. Phospholipid, ethyl oleate, glycerol and pluronic F68 are biocompatible components of the Tan ME that can be safely used for i.v. injection $(16,17)$. The surfactant enhances the permeability of the ME. Our previous study found that empty ME itself had effects on tumor cells (12). Therefore, in the present study, we used two control groups, an empty ME group and a Tan solution group. The results showed that there was no significant difference between the empty ME and Tan solution groups, but there were significant dose-dependent differences in the three Tan ME-treated groups, demonstrating that the ME enhances the antitumor effect of Tan.

As a positive control, 5-Fu had a significant inhibitory effect on the growth of the inoculated H22 cells in mice (the inhibition rate was $65.79 \%$ ) but it significantly decreased the body weight and spleen index of the mice. Compared with the empty ME and Tan solution groups, Tan ME had no significant effects on spleen index and body weight, indicating that Tan ME caused no major side effects in the mice.

It is now well established that apoptosis is a complex biological process involving many pathways. The activation of apoptosis pathways is a key mechanism by which cytotoxic drugs kill tumor cells (18). The induction of apoptosis is now considered to be an important method for the assessment of the clinical effectiveness of antitumor drugs (19). Certain evidence suggests that one of the most important regulators of the apoptotic pathway is the Bcl-2 family of genes, including Bcl-2 and Bax genes (20). One mechanism in the cell death program is the upregulation of the proapoptotic Bax protein. An increase in Bax expression levels effects a change in the permeability of mitochondrial membranes. This leads to the release of cytochrome $\mathrm{c}$ and the activation of caspases, which finally proteolyze cellular components. Bcl-2 is one of the key genes known to downregulate Bax and p53 and therefore has the potency to inhibit this apoptotic pathway (21). $\mathrm{Su}$ and Lin found that Tan IIA inhibited the proliferation of MDA-MB-231 cells in a dose- and time-dependent manner. One of the mechanisms may be through the upregulation of the expression of Bax and the downregulation of Bcl-2 expression and the induction of apoptosis (22).

In conclusion, we demonstrate that, as a drug delivery system, the ME enhances the antitumor effect of Tan. Tan ME had significant anticancer effects in vitro and in vivo, providing a basis for the further development of this novel formulation for a new class of anticancer drugs.

\section{Acknowledgements}

This study was supported by a grant from the Key Science and Technology Program of Liaoning Province, China (Grant No. 2005225013-9).

\section{References}

1. Voiculescu M, Winkler RE, Moscovici M and Neuman MG: Chemotherapies and targeted therapies in advanced hepatocellular carcinoma: from laboratory to clinic. J Gastrointestin Liver Dis 17, 315-322, 2008.

2. Zhang HT, Luo H, Wu J, et al: Galangin induces apoptosis of hepatocellular carcinoma cells via the mitochondrial pathway. World J Gastroenterol 16: 3377-3384, 2010.

3. Tian HL, Yu T, Xu NN, et al: A novel compound modified from tanshinone inhibits tumor growth in vivo via activation of the intrinsic apoptotic pathway. Cancer Lett 297: 18-30, 2010.

4. Du JR, Li X, Zhang R and Qian ZM: Tanshinone inhibits intimal hyperplasia in the ligated carotid artery in mice. J Ethnopharmacol 98: 319-322, 2005.

5. Kai G, Xu H, Zhou C, et al: Metabolic engineering tanshinone biosynthetic pathway in Salvia miltiorrhiza hairy root cultures. Metab Eng 13: 319-327, 2011.

6. Brown D, Lydon J, McLaughlin M, Stuart-Tilley A, Tyszkowski R and Alper S: Antigen retrieval in cryostat tissue sections and cultured cells by treatment with sodium dodecyl sulfate (SDS). Histochem Cell Biol 105: 261-267, 1996.

7. Su CC and Lin YH: Tanshinone IIA down-regulates the protein expression of ErbB-2 and up-regulates TNF- $\alpha$ in colon cancer cells in vitro and in vivo. Int J Mol Med 22: 847-851, 2008.

8. Zhou L, Chan WK, Xu N, et al: Tanshinone IIA, an isolated compound from Salvia miltiorrhiza Bunge, induces apoptosis in HeLa cells through mitotic arrest. Life Sci 83: 394-403, 2008.

9. Han DH, Jin ZH, Jin YZ, Yin XZ, Shen YY and Gao ZG: Thermal reversible microemulsion system for poorly water-soluble YH439 for oral delivery. Chem Pharm Bull (Tokyo) 58: 11-15, 2010.

10. Lawrence MJ and Rees GD: Microemulsion-based media as novel drug delivery systems. Adv Drug Deliv Rev 45: 89-121, 2000.

11. Jadhav KR, Shaikh IM, Ambade KW and Kadam VJ: Applications of microemulsion based drug delivery system. Curr Drug Deliv 3: 267-273, 2006.

12. Fan Q, Fan GJ, Yang PM and Zhao JY: Effect of tanshinone microemulsion on reversing MDR in human tumor cells. Zhongguo Zhong Yao Za Zhi 29: 1079-1081, 2004 (In Chinese).

13. Cibelli M,Fidalgo AR, Terrando N, et al: Role of interleukin-1beta in postoperative cognitive dysfunction. Ann Neurol 68: 360-368, 2010.

14. Yan D, Bao HY, Bau T, Li Y and Kim YH: Antitumor components from Naematoloma fasciculare. J Microbiol Biotechnol 19: 1135-1138, 2009.

15. Sawada K, Kalam-Azad A, Sakata-Haga H, Lee NS, Jeong YG and Fukui Y: Striking pattern of Purkinje cell loss in cerebellum of an ataxic mutant mouse, tottering. Acta Neurobiol Exp (Warsaw) 69: 138-145, 2009.

16. Nornoo AO, Osborne DW and Chow DS: Cremophor-free intravenous microemulsions for paclitaxel I: formulation, cytotoxicity and hemolysis. Int J Pharm 349: 108-116, 2008.

17. Tsai YH, Hsieh YH, Huang YB, Chang JS, Huang CT and Wu PC: Microemulsions for intravesical delivery of gemcitabine. Chem Pharm Bull (Tokyo) 58: 1461-1465, 2010.

18. Debatin KM: Apoptosis pathways in cancer and cancer therapy. Cancer Immunol Immunother 53: 153-159, 2004.

19. Liu XD, Fan RF, Zhang Y, et al: Down-regulation of telomerase activity and activation of caspase-3 are responsible for tanshinone I-induced apoptosis in monocyte leukemia cells in vitro. Int $\mathrm{J}$ Mol Sci 11: 2267-2280, 2010.

20. Wang W, Guo QL, You QD, et al: The anticancer activities of wogonin in murine sarcoma S180 both in vitro and in vivo. Biol Pharm Bull 29: 1132-1137, 2006.

21. Kernt M, Neubauer AS, Eibl KH, et al: Minocycline is cytoprotective in human trabecular meshwork cells and optic nerve head astrocytes by increasing expression of XIAP, survivin, and Bcl-2. Clin Ophthalmol 4: 591-604, 2010.

22. Su CC and Lin YH: Tanshinone IIA inhibits human breast cancer cells through increased Bax to Bcl-xL ratios. Int J Mol Med 22: 357-361, 2008. 